Original article

Section: Food Technology

\title{
Drying Kinetics and Changes of Total Phenolic Content, Antioxidant Activity and Color Parameters of Mango and Avocado Pulp in Refractance Window Drying
}

\author{
Thi-Van-Linh Nguyen ${ }^{1, *}{ }^{\oplus}$, Quoc-Duy Nguyen ${ }^{1} \odot$,Phuoc-Bao-Duy Nguyen $^{2,3}$ \\ ${ }^{I}$ Faculty of Environmental and Food Engineering, Nguyen Tat Thanh University, \\ 300A Nguyen Tat Thanh Street, District 4, Ho Chi Minh City, Vietnam \\ ${ }^{2}$ Faculty of Electrical and Electronics Engineering, Ho Chi Minh University of Technology (HCMUT), \\ 268 Ly Thuong Kiet Street, District 10, Ho Chi Minh City, Vietnam \\ ${ }^{3}$ Vietnam National University Ho Chi Minh City, Linh Trung Ward, Thu Duc District, Ho Chi Minh City, Vietnam
}

Key words: avocado pulp, mango pulp, refractance window drying, drying kinetics, phenolics, color parameters

Refractance window drying is an innovative technology belonging to the fourth generation of drying technologies that could enhance the quality of the dried product and improve the drying process. In this study, two factors with the type of fruit pulps (avocado and mango) and drying temperature (ranging from 80 to $95^{\circ} \mathrm{C}$ ) were investigated. Results showed that in refractance window drying, the evaporation process rapidly occurred, mainly in the falling-rate period with undetectable constant-rate period. The Weibull was the best fit model among eight investigated mathematical models that could determine the drying behavior. The effective diffusivity was found to be from $4.25 \times 10^{-10} \mathrm{~m}^{2} / \mathrm{s}$ to $7.24 \times 10^{-10} \mathrm{~m}^{2} / \mathrm{s}$ for avocado pulp, and from $4.50 \times 10^{-10} \mathrm{~m}^{2} / \mathrm{s}$ to $10.67 \times 10^{-10} \mathrm{~m}^{2} / \mathrm{s}$ for mango pulp when the drying temperature was changed from 80 to $95^{\circ} \mathrm{C}$. Moreover, the corresponding activation energy was 32.06 and $66.03 \mathrm{~kJ} / \mathrm{mol}$ for avocado and mango pulp moisture evaporation, respectively, and the highest quality of powders of both dried pulps was obtained after processing at $90^{\circ} \mathrm{C}$. The refractance window drying revealed a high potential in the production of fruit powders from avocado and mango due to the high retention of more than $80 \%$ of total phenolic content (TPC) and antioxidant activity. TPC could be used as a useful criterion for the evaluation of the drying process in terms of dried product quality.

\section{INTRODUCTION}

Drying technology is a traditional unit operation that is most popular and important in food processing and preservation. During the drying process, moisture is removed from the material to enhance the stability of the product, reduce unexpected reactions, extend shelf-life, and produce dried products. Among dried products, powder from fruits and vegetables has been shown to offer exciting benefits as very convenient in developing industrial products such as beverages, baby foods, sauces, confectionery, yogurt, ice cream, nutritional bars, bakery products, and cereals [Ramaswamy $\&$ Marcotte, 2005]. Besides, the use of fruit powders entails lower costs of distribution and storage [Zotarelli et al., 2017]. In the literature, some drying methods, such as spray-, drum-, freeze-drying, have been studied in respect of fruit powder production. However, each drying method had still some significant drawbacks related to the quality of powder (spray- and drum drying) or costs of system maintenance and implementation (freeze-drying). Recently, the fourth generation of drying technologies has been developed to enhance the quality of the dried product and improve the drying process, among which the refractance window (RW) drying is an innovative technology designed to remove moisture from fruit purees to produce powder, dried sheets, or concentrated products [Vega-Mercado et al., 2001]. During the RW drying, the heat conduction from hot water to film interface is dominant and the drying material would absorb energy due to heat conduction from plastic film to force moisture diffusion and evaporation. While heat conduction, convection, and radiation also happen at the hot-water interface and convection occurs at the air-film interface [Raghavi et al., 2018].

In RW drying, the nutritional and sensory values were proved to be preserved effectively, bringing health benefits to consumers [Nindo \& Tang, 2007]. In the literature, the RW drying was successfully applied to fruits and vegetables such as carrot, strawberry [Nindo \& Tang, 2007], and tomato [Abul-Fadl \& Ghanem, 2011]. As a consequence, the nutritional quality (especially vitamin contents) and the sensory values (color, flavor) could be highly retained [Nindo \&

\footnotetext{
* Corresponding Author:

E-mail: ntvlinh@ntt.edu.vn (Thi-Van-Linh Nguyen)
} 
Tang, 2007]. For example, the bright green color of asparagus puree after the RW drying was retained similarly to freeze-drying [Abonyi et al., 2002]. Additionally, thermal efficiency in RW drying was also higher than using convective drying equipment, as illustrated by the reduction of $50-70 \%$ in costs and $50 \%$ in energy consumption compared to freeze-drying in the same material capacity [Nindo \& Tang, 2007].

Among food materials, avocado and mango are fascinating objects of study. Avocado fruits are superfoods rich in nutrients and phytochemicals [Comerford et al., 2016]. Mango possesses high nutritional value [Abbasi et al., 2015; Haytowitz et al., 2018; Shariful et al., 2015]. It belongs to the group of tropical fruits with the top increased consumption with high economic value [Fitzpatrick \& Ahrné, 2005; Occena-Po, 2006]. Although both avocado and mango have great nutritional and economic values, they have considerable limitations when it comes to moisture removal. In the literature, some drying methods were applied to dehydrate avocado, such as freeze-drying [Castañeda-Saucedo et al., 2014; Rafidah et al., 2014; Souza et al., 2015], hot-air drying [Temu, 2013], heat-pump drying [Ceylan et al., 2007], or superheated-steam drying [Rafidah et al., 2014]. The most critical drawback in these studies is the long operating time (varying from 3 to more than $20 \mathrm{~h}$ ), because the higher the temperature or the longer the time of avocado thermal treatment, the more bitter-tasting molecules are produced [Degenhardt \& Hofmann, 2010]. However, Degenhardt \& Hofmann [2010] found that the thermal processing of avocado within $30 \mathrm{~min}$ (at temperatures ranging from 80 to $120^{\circ} \mathrm{C}$ ) or $60 \mathrm{~min}\left(\right.$ at $80^{\circ} \mathrm{C}$ ) only slightly increased bitter taste in comparison with untreated avocado. Thus, the higher quality of dried avocado will be obtained if the temperature and duration of drying are well controlled. In the case of mango, the reported drying methods included freeze- [Caparino et al., 2012], drum- [Caparino et al., 2012; Germer et al., 2018], spray- [Cano-Chauca et al., 2005; Caparino et al., 2012; Zotarelli et al., 2017], spout fluidized bed- [da Cunha et al., 2006], vacuum- [Jaya et al., 2006], hot air- [Yao et al., 2020], infrared- [Yao et al., 2020], foam mat[Chaux-Gutiérrez et al., 2017], and RW drying [Caparino et al., 2012, 2017; Zotarelli et al., 2015, 2017]. Most of these studies were focused on drying kinetics and physicochemical analysis. A few publications reported about the effect of drying on the quality of dried mango, including the determination of ascorbic acid and $\beta$-carotene contents without the analysis of total phenolic content (TPC) and antioxidant activity. Caparino et al. [2017] studied mango powder obtained using RW drying, but the results they achieved showed the physical and chemical stability of mango powder during storage [Caparino et al., 2017]. Mango powder obtained using RW drying had a better physical quality than that produced using drum-drying and spray-drying [Caparino et al., 2012; Zotarelli et al., 2017].

In the literature, the RW drying was conducted for mango pulp [Caparino et al., 2012] and low-fat avocado paste [Da Silva \& Da Silva, 2018]. However, there is still a limited number of studies on drying kinetics of RW drying of avocado and mango. Only the change of physicochemical properties under the effects of drying conditions was reported. In the field of the drying process, studies on drying kinetics and the change of quality upon drying are always essential to evaluate the drying process and choose its suitable conditions [Onwude et al., 2016]. The application of innovative drying, such as the RW drying, was expected to produce high-quality dried avocado and mango.

Therefore, this study aimed to investigate the drying kinetics and the changes of TPC, antioxidant activity and color parameters of avocado and mango pulp exposed to RW drying at different drying temperatures. The experimental data was used to determine the drying behavior, the effective diffusivity coefficients, activation energy and quality of dried products. These results would support the identification of suitable conditions of avocado and mango pulp drying.

\section{MATERIALS AND METHODS}

\section{Material preparation}

Fresh avocado (Persea americana) and mango (Mangifera indica) were received from a local farm in DakLak and Ben Tre, Vietnam. The fully-ripe avocado and mango without the physical damages were chosen. Then, materials were washed, peeled, and sliced using a fruit knife (Royal VKB, China). Slices were pretreated with steam for $3 \mathrm{~min}$ to inactivate enzymes responsible for the browning phenomena, such as polyphenol oxidase and peroxidase. After steaming, slices were cooled promptly in cold water at $5.0 \pm 0.5^{\circ} \mathrm{C}$. Fruit pulp was then produced using a Berjaya commercial blender (BJY-CB2L60-A, Kuala Lumpur, Malaysia) and passed through 16-mesh sieves to remove large particles and fibers. Before drying, 9\% (w/w) maltodextrin was added to pulps to act as a coating material, creating a physical barrier to oxygen and light to protect against chemical and enzymatic degradation [Wang et al., 2009]. Our previous study demonstrated that the addition of maltodextrin $(9 \%, w / w)$ improved the quality of dried products and facilitated the grinding to produce fruit powder (data not shown).

\section{Refractance window drying apparatus}

A custom-built refractance window drying equipment was set up with a similar principle in previous researches [Parisotto et al., 2020; Rajoriya et al., 2019] with some modifications. The drying apparatus was operated in batch laboratory-scale configuration and consisted of a hot water reservoir $(0.42 \mathrm{~m} \times 0.28 \mathrm{~m} \times 0.10 \mathrm{~m})$ and a thermostatic water bath (DH.WB000106, Daihan-Scientific, Wonju-si, South Korea). A polyester film (Mylar ${ }^{\mathrm{TM}}$, Jiangsu, China) with a $0.25-\mathrm{mm}$ thickness was used to conduct heat from hot water to fruit pulp spread into 2-mm-thick layers on the films.

\section{Experimental design and refractance window drying operation}

In this study, the experiments were conducted with two factors, including the pulp types (avocado pulp - AP and mango pulp - MP) and 4-level drying temperature (from 80 to $95^{\circ} \mathrm{C}$ at an interval of $5^{\circ} \mathrm{C}$ ) with three replications.

Each pulp sample was dried using the RW drying system and moisture content was analyzed at 5-min intervals. The drying process was stopped when the moisture content reached of $0.04 \mathrm{~g} / \mathrm{g}$ on the dry basis (d.b.). The moisture 
content was determined by the moisture analyzer with infrared heating (MB23, Ohaus, Parsippany, NJ, USA). Experiment data was used to determine the mathematical model and kinetic parameters in the RW drying of AP and MP.

To determine the quality of AP and MP after drying, each pulp sample (100 g) was dried to a moisture content of $0.040 \pm 0.005 \mathrm{~g} / \mathrm{g}$ d.b., and dried products were collected. Then, these products were ground to powder for future determination of TPC, antioxidant activity, and color parameters.

\section{Mathematical models for thin-layer drying curves}

The moisture ratio (MR) was determined using the following equation [Pala et al., 1996]:

$$
\mathrm{MR}=\frac{\mathrm{M}_{\mathrm{t}}}{\mathrm{M}_{0}}
$$

where: $\mathrm{M}_{\mathrm{t}}$ is moisture content at $\mathrm{t}$ drying time ( $\mathrm{g}$ water/g d.b.) and $\mathrm{M}_{0}$ is the initial moisture content ( $\mathrm{g}$ water/g d.b.).

Of the many mathematical models suggested to determine the drying characteristics of food products [Onwude et al., 2016], this study fitted drying curves to the eight semi-theoretical and empirical models including Newton, Page, Modified Page (II), Modified Page (IV), Henderson \& Pabis, Logarithmic, Midilli, and Weibull models. Statistical parameters, including the determination coefficient $\left(\mathrm{R}^{2}\right)$ and the root mean square error (RMSE), were determined to identify the ability to predict the tested models:

$$
\begin{aligned}
& \mathrm{R}^{2}=1-\frac{\sum_{\mathrm{i}=1}^{\mathrm{N}}\left(\mathrm{M}_{\mathrm{exp}, \mathrm{i}}-\mathrm{M}_{\mathrm{pre}, \mathrm{i}}\right)^{2}}{\sum_{\mathrm{i}=1}^{\mathrm{N}}\left(\overline{\mathrm{MR}_{\mathrm{exp}}}-\mathrm{MR}_{\mathrm{pre}, \mathrm{i}}\right)^{2}} \\
& \mathrm{RMSE}=\sqrt{\frac{1}{\mathrm{~N}} \sum_{\mathrm{i}=1}^{\mathrm{N}}\left(\mathrm{M}_{\mathrm{exp}, \mathrm{i}}-\mathrm{M}_{\mathrm{pre}, \mathrm{i}}\right)^{2}}
\end{aligned}
$$

where: $M_{\text {exp,i }}$ is the experimental dimensionless moisture ratio, $M_{\text {pre, } i}$ is the predicted dimensionless moisture ratio, $\overline{\mathrm{MR}_{\text {exp }}}$ is the mean value of the experimental dimensionless moisture ratio, and $\mathrm{N}$ is the number of observations.

\section{Determination of the effective diffusivity}

Fick's second law of diffusion was chosen to determine moisture movement within the mango and avocado pulp, considered an infinite flat plate. The diffusion equation is as follows:

$$
\frac{\partial \mathrm{M}}{\partial \mathrm{t}}=\mathrm{D}_{\mathrm{eff}} \nabla^{2} \mathrm{M}
$$

where: $\mathrm{M}$ is the moisture content (g water/g d.b.), $\mathrm{D}_{\text {eff }}$ is the effective moisture diffusivity $\left(\mathrm{m}^{2} / \mathrm{s}\right)$, and $\mathrm{t}$ is the time $(\mathrm{s})$.

Crank [1975] gave a general analytical solution for thinlayer drying case with some assumptions such as the product with homogeneous, isotropic sizes, and constant characteristics; negligible shrinkage, negligible external resistance to heat and mass transfer; evaporation only at product surface; uniform initial moisture distribution; constant of the moisture diffusivity. The solution was given as:

$\mathrm{MR}=\frac{8}{\pi^{2}} \sum_{\mathrm{n}=0}^{\infty} \frac{1}{(2 \mathrm{n}+1)^{2}} \exp \left(-(2 \mathrm{n}+1)^{2} \pi^{2} \frac{\mathrm{D}_{\text {eff }}}{\mathrm{L}^{2}} \mathrm{t}\right)$

where: MR is the dimensionless moisture ratio, $\mathrm{L}$ is the layer thickness ( $\mathrm{m}), \mathrm{n}$ is the term in series expansion, and $\mathrm{t}$ is time (s).

For long drying times, the first term in the above series expansion $(n=0)$ was considered as an approximate solution:

$$
\mathrm{MR}=\frac{8}{\pi^{2}} \exp \left(-\pi^{2} \frac{\mathrm{D}_{\mathrm{eff}}}{\mathrm{L}^{2}} \mathrm{t}\right)
$$

The effective diffusivity $\left(\mathrm{D}_{\text {eff }}\right)$ was found on the basis of Eq. 6 by the non-linear least square method using the Levenberg-Marquardt algorithm [Marquardt, 1963].

\section{Determination of activation energy}

The activation energy $\left(\mathrm{E}_{\mathrm{a}}\right)$ of moisture removal was estimated from an Arrhenius equation, and it was given as:

$$
\mathrm{D}_{\mathrm{eff}}=\mathrm{D}_{0} \exp \left(-\frac{\mathrm{E}_{\mathrm{a}}}{\mathrm{RT}}\right)
$$

where: $\mathrm{E}_{\mathrm{a}}$ is the activation energy $(\mathrm{kJ} / \mathrm{mol}), \mathrm{R}$ is the ideal gas constant $(8.3143 \mathrm{~kJ} / \mathrm{mol}), \mathrm{T}$ is the absolute temperature $(\mathrm{K})$, and $\mathrm{D}_{0}$ is the pre-exponential factor $\left(\mathrm{m}^{2} / \mathrm{s}\right)$.

\section{Preparation of extracts}

The preparation of extracts from avocado and mango pulps was performed according to Wang et al. [2010] and Bloor [2001] procedures, respectively, with some modifications. The AP $(0.2 \mathrm{~g})$ was mixed with $10 \mathrm{~mL}$ of the solvent $(7 \mathrm{~mL}$ acetone $+0.03 \mathrm{~mL}$ glacial acetic acid $+2.97 \mathrm{~mL}$ water $)$, and the MP $(0.5 \mathrm{~g})$ was mixed with $10 \mathrm{~mL}$ of the solvent (6 mL methanol $+4 \mathrm{~mL}$ water). The suspensions were vortexed for $30 \mathrm{~s}$ at 2,000 rpm using the VELP ZX4 advanced IR vortex mixer (VELP Scientifica, Milan, Italy). Then, after sonication (40 KHz, $240 \mathrm{~W}, 5 \mathrm{~min}$ ) in the Pro 100 ultrasonic cleaner (Asonic, Ljubljana, Slovenia), the samples were again vortexed for $10 \mathrm{~s}$ and cooled for $20 \mathrm{~min}$ at $10^{\circ} \mathrm{C}$. The cooled samples were then sonicated for a second time at the previous conditions and centrifuged in the PLC-05 centrifuge (Gemmy Industrial Corp., Taipei, Taiwan) at $1,220 \times g$ for $10 \mathrm{~min}$. The supernatant was collected and diluted to $25 \mathrm{~mL}$ to analyze TPC and DPPH radical scavenging activity.

\section{Determination of total phenolic content}

The total phenolic content of the extract was determined according to ISO 14502-1:2005 [2005] method. Briefly, $0.6 \mathrm{~mL}$ of the extract was mixed with $1.5 \mathrm{~mL}$ of the Folin-Ciocalteu reagent (10-fold dilution) and allowed to stand for 
$5 \mathrm{~min}$ at room temperature. Then, $1.2 \mathrm{~mL}$ of $7.5 \% \mathrm{Na}_{2} \mathrm{CO}_{3}$ solution was added, and the mixture was incubated for $1 \mathrm{~h}$ in the dark. Finally, the absorbance of the mixture was measured at $765 \mathrm{~nm}$ using the UV-9000 spectrometer (Metash, Shanghai, China). TPC was determined through the gallic acid standard curve and expressed as mg gallic acid equivalent per $\mathrm{g}$ of pulp on the dried basis (mg GAE/g d.b.). For the dried powders, the retention percentage of TPC was calculated on the basis of the ratio of TPC of powdered pulp to TPC of pulp before drying.

\section{Determination of antioxidant activity}

The 2,2-diphenyl-1-picrylhydrazyl (DPPH) radical scavenging activity of the extract was determined according to Brand-Williams et al. [1995] with minor changes. To prepare the radical stock solution, $24 \mathrm{mg}$ of solid $\mathrm{DPPH}^{*}$ were dissolved in $100 \mathrm{~mL}$ of methanol and stored at $4^{\circ} \mathrm{C}$ in the dark for $24 \mathrm{~h}$. The DPPH ${ }^{\circ}$ working solution was prepared by diluting the $\mathrm{DPPH}^{*}$ stock solution to the absorbance of 1.1 units at $515 \mathrm{~nm}$ using methanol. Then, $150 \mathrm{~mL}$ of the extract was reacted with $2850 \mathrm{~mL}$ of $\mathrm{DPPH}{ }^{*}$ working solution for 30 min under dark conditions. Finally, the absorbance of the mixture was measured at $515 \mathrm{~nm}$ over methanol blank. In parallel, the standard curve for Trolox was prepared and DPPH radical scavenging activity was expressed as mg Trolox equivalent per $\mathrm{g}$ of pulp on the dried basis (mg TE/g d.b.). For the dried powders, the retention percentage of antioxidant activity was calculated on the basis of the ratio of $\mathrm{DPPH}^{*}$ scavenging activity of powdered pulp to $\mathrm{DPPH}^{*}$ scavenging activity of pulp before drying.

\section{Determination of color attributes}

The values of $L^{*}, a^{*}$, and $b^{*}$ color parameters were measured with the NR110 precision colorimeter (Shenzhen 3nh Technology Co., Guangdong, China) using the Hunter CIELAB color system. $L^{*}$ indicates lightness, with a scale ranging from 0 (black) to 100 (white). Positives and negatives in $a^{*}$ represent red and green, whereas positives and negatives in $b^{*}$ represent yellow and blue, respectively.

\section{Statistical analysis}

All experiments were conducted in triplicate. The mean and standard deviation were calculated in WPS Spreadsheets software (Microsoft Inc., Redmond, WA, USA). The coefficients of mathematical models were found by the non-linear least square method based on the Levenberg-Marquardt algorithm. One-way analysis of variance (ANOVA) was used to determine the differences between samples, and Tukey's multiple range test was applied to determine significant differences between mean values at the significance level of $5 \%$. Pearson correlation was also calculated to determine the coefficients between TPC, antioxidant activity and color parameters of avocado and mango powders.

\section{RESULTS AND DISCUSSION}

\section{Quality of avocado and mango pulp}

Before performing the drying experiments, the materials were standardized and analyzed for the physicochemical properties. Table 1 shows the chemical composition of fresh
TABLE 1. The physicochemical properties of avocado and mango pulp.

\begin{tabular}{lccc}
\hline Properties & Avocado pulp & Mango pulp \\
\hline $\begin{array}{l}\text { Moisture } \\
\text { (g/100 g fresh pulp) }\end{array}$ & $82.4 \pm 0.5$ & $90.03 \pm 0.68$ \\
$\begin{array}{l}\text { Total phenolic content } \\
\text { (mg GAE/g d.b.) }\end{array}$ & $5.33 \pm 0.06$ & $23.18 \pm 0.45$ \\
$\begin{array}{l}\text { Antioxidant activity } \\
\text { (mg TE/g d.b.) }\end{array}$ & $1.60 \pm 0.05$ & $6.31 \pm 0.66$ \\
\hline & $L^{*}$ & $61.05 \pm 1.02$ & $66.63 \pm 0.52$ \\
Color parameters & $a^{*}$ & $-23.77 \pm 1.17$ & $3.41 \pm 0.94$ \\
& $b^{*}$ & $55.05 \pm 1.09$ & $62.51 \pm 0.80$ \\
\hline
\end{tabular}

GAE - gallic acid equivalents; TE - Trolox equivalents; d.b. - dry basis.

avocado and mango pulp. The moisture content in avocado pulp $(82.4 \pm 0.5 \mathrm{~g} / 100 \mathrm{~g})$ and mango pulp $(90.03 \pm 0.68 \mathrm{~g} / 100 \mathrm{~g})$ were significantly different from these shown in previous studies for avocado [Kassim et al., 2013; Lye et al., 2020] and mango [Jaya \& Das, 2003; Pu \& Sun, 2017]. Differences in variety, culture, soil properties, ripeness stage, harvest time, and post-harvest handling could all contribute to this variation. Table 1 shows that the mango pulp had a higher content of total phenolics and antioxidant activity than avocado pulp.

\section{Drying curves and drying rate}

The changes of moisture content during RW drying of AP and MP at different drying temperatures are shown in Figure 1 and Figure 2, respectively. The results revealed that the higher the RW temperature was, the shorter was the drying time. Specifically, when the temperature increased from 80 to $95^{\circ} \mathrm{C}$, it would consume from 70 to $40 \mathrm{~min}$ for $\mathrm{AP}$ and from 85 to $45 \mathrm{~min}$ for MP to remove moisture from the initial moisture content to $0.040 \mathrm{~g} / \mathrm{g}$ d.b., respectively. Figure $1 \mathrm{~b}$ and Figure $2 \mathrm{~b}$ present the drying rate versus moisture content during RW drying of $\mathrm{AP}$ and $\mathrm{MP}$ at different temperatures. The results showed that the higher the RW drying temperature was, the higher was the drying rate. It was clear that the higher RW drying temperature could increase the absorbed heat energy transferred from hot water to materials [Raghavi et al., 2018]. Then, the more considerable heat rising in the material was, the faster was internal and external moisture diffusion. Therefore, the higher RW drying temperature would increase the drying rate and significantly reduce drying time.

For RW drying of AP, it was observed that the drying process only happened in the falling-rate period with the undetectable constant-rate period (Figure 1b). Meanwhile, there are two periods, including (i) the pre-heating period in the first $5 \mathrm{~min}$ of the drying process, and (ii) the falling-rate period for RW drying of MP (Figure 2b). Therefore, the RW drying of AP and MP mainly occurred in the falling-rate period. This phenomenon is because the conditions required for constant rate drying are seldom met [Berk, 2018], leading to all of the practical dryings of biological products taking place in the falling-rate period [Madamba et al., 1996]. Also, most of the studies on drying have supported this conclusion [Onwude et al., 2016]. Besides, the evaporation process happened rapidly in drying, causing the drying to occur only in the falling-rate period. In this study, the material grinding could release free 
water from the vacuole and the xylem, so it was easy to evaporate when the pulp was spread into thin layers and quickly heated. That caused the moisture removal in RW drying of AP and MP to happen very fast. Similar observations were reported in the literature for RW drying of tomato [Abul-Fadl \& Ghanem, 2011], murta berry leather [Gómez-Pérez et al., 2020], and mango slices [Ochoa-Martínez et al., 2012].

The drying rates were found to be positively correlated with moisture content. At the beginning of the drying process, it was observed that all samples had a higher drying rate (Figure 1 and Figure 2). Continuing the drying process, the drying rate decreased during moisture removal. Initially, the moisture content in the material was high; the heat energy from hot water transferred to materials would force water evaporation faster. Subsequently, the driving force of moisture removal was reduced. Because of the rubbery-glassy phase transition of the material, the critical phenomenon during drying would change the material from soft and rubbery to hard and glassy [Gulati \& Datta, 2015]. Plus, when most of the free water escaped, heat energy was mainly responsible for breaking the water bonding, then diffusing moisture to evaporate. Therefore, the smaller moisture content was, the slower was the drying rate in the RW drying of AP and MP.

\section{Mathematical model for RW drying of AP and MP}

Changes in moisture ratio during RW drying of $\mathrm{AP}$ and MP were used to evaluate the fitting of mathematical models, and then to figure out the best model describing the behavior of RW drying of AP and MP. The selection was based on statistical parameters, including the coefficient of determination $\left(\mathrm{R}^{2}\right)$ and root-mean-square error (RMSE) (Table 2).

The thin-layer model, which has the highest $\mathrm{R}^{2}$ value and smallest RMSE, was the best in this study. The average $\mathrm{R}^{2}$ and RMSE were calculated to be convenient to compare the predicted power of mathematical models. The results showed that the higher the $\mathrm{R}^{2}$ value was, the smaller was the RMSE. Among eight investigated models, the order of decreasing the average value of $\mathrm{R}^{2}$ was as follows: (i) for RW drying of AP: Weibull > Midilli > Logarithmic > Modified Page (IV), Modified Page (II) and Page $>$ Henderson \& Pabis $>$ Newton, and (ii) for RW drying of MP: Weibull > Midilli > Modified Page (IV) $>$ Modified Page (II) and Page $>$ Logarithmic $>$ Henderson \& Pabis $>$ Newton.

The Newton model is the simplest model for determining the behavior of the drying process and the Henderson \& Pabis model was developed from the first term in the numerical solution of Fick's second law of diffusion equation [Onwude

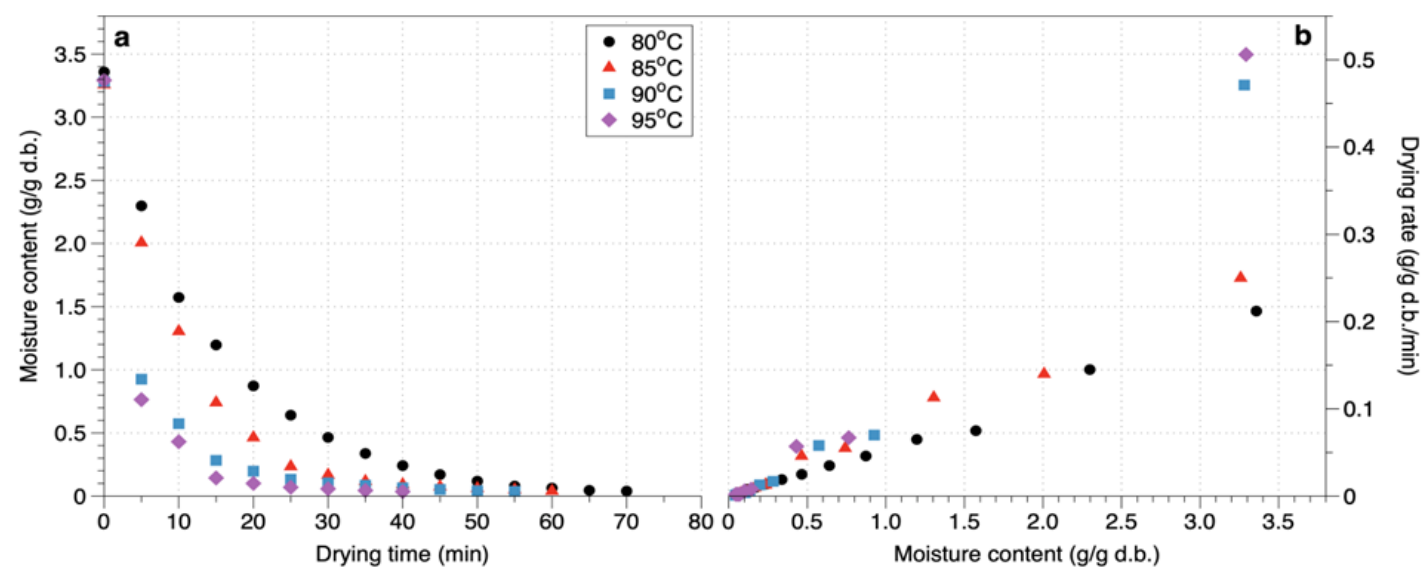

FIGURE 1. The changes of moisture content (a) and the drying rate curves (b) in refractance window drying of avocado pulp at different temperatures.

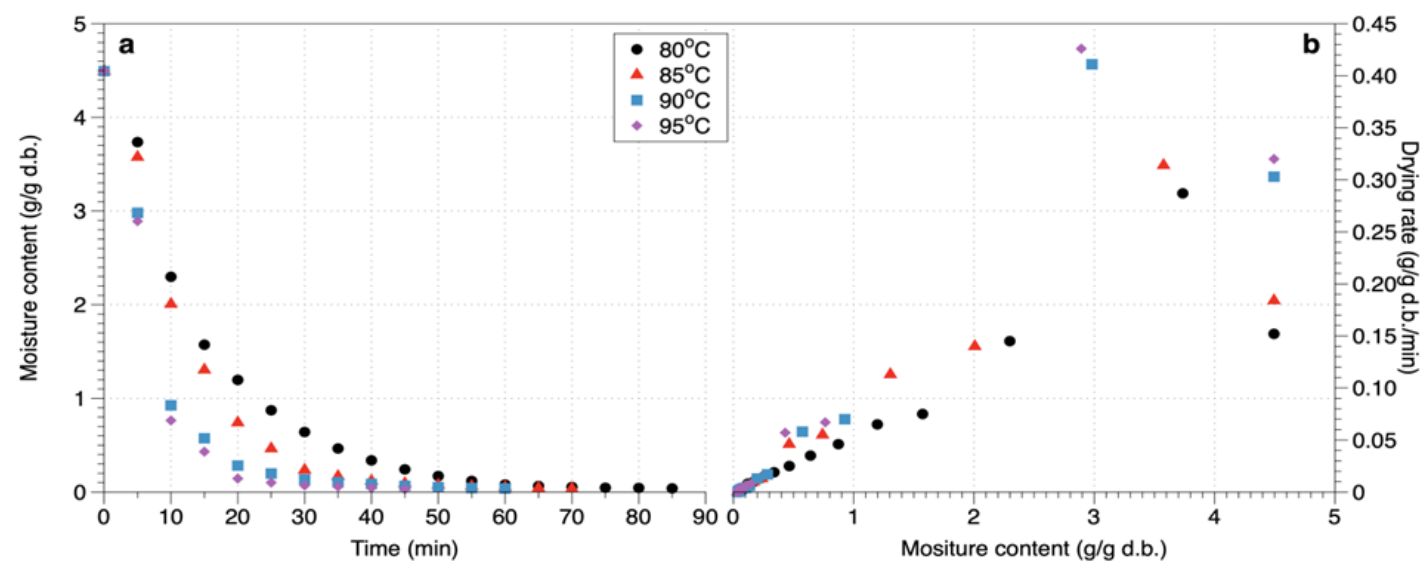

FIGURE 2. The changes of moisture content (a) and the drying rate curves (b) in refractance window drying of mango pulp at different temperatures. 


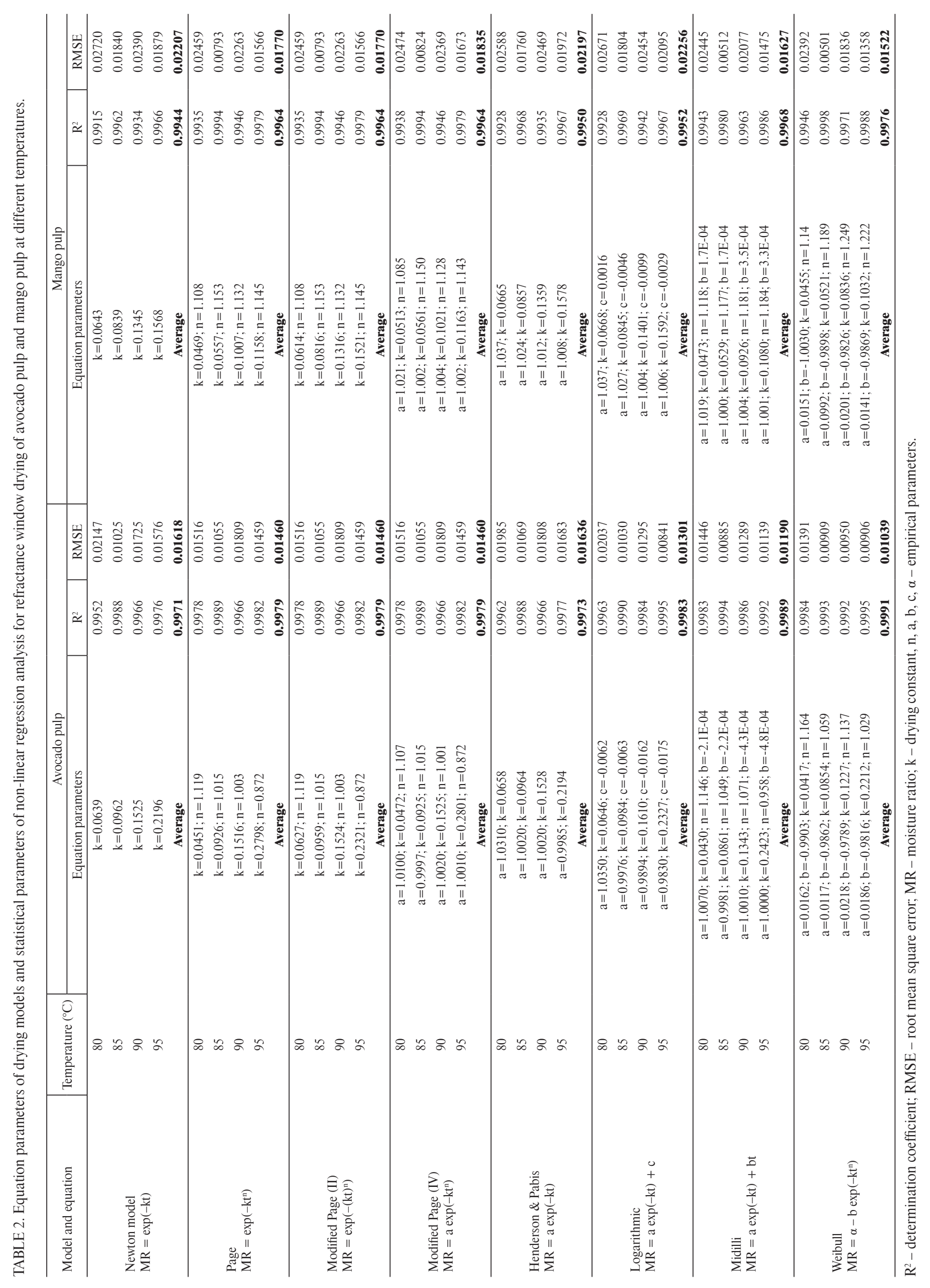


et al., 2016]. Both the Newton and Henderson \& Pabis models had the lowest power of prediction in the change of moisture ratio during RW drying of AP and MP (Table 2). From Newton and Henderson \& Pabis model, the Logarithmic, Page, Modified Page (II), Modified Page (IV) were developed by either addition of the constant "c" or a dimensionless empirical constant " $n$ ". The experimental data from this study showed the ability in prediction was higher in developed models (higher $\mathrm{R}^{2}$ and lower RMSE values) (Table 2). Midilli and Weibull models were inserted both a dimensionless empirical constant " $n$ " or linear term "bt" and the constant "a", respectively. That was the reason why Midilli and Weibull models had the highest power of prediction.

In the literature review, Onwude et al. [2016] pointed to many studies in which it was concluded that the Midilli model was the most suitable in determining the thin-layer drying characteristics of fruits and vegetables. However, these studies were carried out without analyzing the Weibull model. Only a few publications conducted evaluations of both the Midilli and Weibull models. They confirmed that both of them were suitable to represent the behavior of the thin-layer drying of persimmon slices [Doymaz, 2012] and lemongrass [Nguyen et al., 2019]. However, in our study, the Weibull model was the best fit model among the investigated models with the highest value of $\mathrm{R}^{2}$ and lowest RMSE values. Some previous studies showed that the Weibull model could characterize the drying behavior of mango slices [Corzo et al., 2010], pepino fruit [Uribe et al., 2011], quince slices [Tzempelikos et al., 2015] and yam slices [Ju et al., 2018].

\section{Effective diffusivity and activation energy}

During the drying process, the mechanism of moisture transport is not known precisely. Therefore, numerous studies used effective diffusivity as a valid value to determine the ability of moisture removal from different materials using different drying methods. In this study, the effective diffusivity (with $\mathrm{R}^{2}$ values) for RW drying of $\mathrm{AP}$ and MP was found and presented in Table 3, which also shows the activation energy for moisture removal (with $\mathrm{R}^{2}$ values) for $\mathrm{AP}$ and $\mathrm{MP}$ in RW drying.

The result revealed that when the RW drying temperature was increased from 80 to $95^{\circ} \mathrm{C}, \mathrm{D}_{\text {eff }}$ would increase from $4.25 \times 10^{-10} \mathrm{~m}^{2} / \mathrm{s}$ to $7.24 \times 10^{-10} \mathrm{~m}^{2} / \mathrm{s}$ for $\mathrm{AP}$, and from $4.50 \times$ $\times 10^{-10} \mathrm{~m}^{2} / \mathrm{s}$ to $10.67 \times 10^{-10} \mathrm{~m}^{2} / \mathrm{s}$ for MP. The range of these $\mathrm{D}_{\text {eff }}$ values was from $10^{-11}$ to $10^{-8} \mathrm{~m}^{2} / \mathrm{s}$ when dealing with thinlayer food drying [Onwude et al., 2016]. It seems that the increase in $\mathrm{D}_{\text {eff }}$ with the temperature was mainly due to a higher hot water temperature in which a more significant amount of thermal energy was transferred into materials leading to faster movement of the water molecules from inside to the surface to evaporate. Some studies in RW drying showed similar results [Rajoriya et al., 2019, 2021]. In the literature, the $\mathrm{D}_{\text {eff }}$ values in drying of AP are still limited. For mango, Corzo et al. [2008] obtained values of $\mathrm{D}_{\text {eff }}$ changing from $1.74 \times 10^{-10}$ to $3.15 \times 10^{-10} \mathrm{~m}^{2} / \mathrm{s}$ and from $2.30 \times 10^{-10}$ to $3.28 \times 10^{-10} \mathrm{~m}^{2} / \mathrm{s}$ for green and half-ripe mango, respectively, when the air-drying temperature varied from 50 to $80^{\circ} \mathrm{C}$ [Corzo et al., 2008].

The activation energy for AP and MP moisture evaporation was 32.06 and $66.03 \mathrm{~kJ} / \mathrm{mol}$ in RW drying, respectively.
TABLE 3 . The effective diffusivity $\left(\mathrm{D}_{\text {eff }}\right)$ and the activation energy $\left(\mathrm{E}_{\mathrm{a}}\right)$ in refractance window drying of avocado pulp and mango pulp

\begin{tabular}{|c|c|c|c|c|c|}
\hline Material & $\begin{array}{c}\text { Temperature } \\
\left({ }^{\circ} \mathrm{C}\right)\end{array}$ & $\mathrm{D}_{\text {eff }}\left(\mathrm{m}^{2} / \mathrm{s}\right)$ & $\mathrm{R}^{2}$ & $\begin{array}{c}\mathrm{E}_{\mathrm{a}} \\
(\mathrm{kJ} / \mathrm{mol})\end{array}$ & $\mathrm{R}^{2}$ \\
\hline \multirow{4}{*}{$\begin{array}{l}\text { Avocado } \\
\text { pulp }\end{array}$} & 80 & $4.45 \times 10^{-10}$ & 0.9978 & \multirow{4}{*}{32.06} & \multirow{4}{*}{0.8363} \\
\hline & 85 & $5.02 \times 10^{-10}$ & 0.9610 & & \\
\hline & 90 & $5.15 \times 10^{-10}$ & 0.9083 & & \\
\hline & 95 & $7.24 \times 10^{-10}$ & 0.9138 & & \\
\hline \multirow{4}{*}{$\begin{array}{l}\text { Mango } \\
\text { pulp }\end{array}$} & 80 & $4.50 \times 10^{-10}$ & 0.9928 & \multirow{4}{*}{66.03} & \multirow{4}{*}{0.9678} \\
\hline & 85 & $5.79 \times 10^{-10}$ & 0.9968 & & \\
\hline & 90 & $9.19 \times 10^{-10}$ & 0.9935 & & \\
\hline & 95 & $10.67 \times 10^{-10}$ & 0.9967 & & \\
\hline
\end{tabular}

$\mathrm{R}^{2}$ - coefficient of determination.

In the literature review of Onwude et al. [2016], most publications found $\mathrm{E}_{\mathrm{a}}$ values for thin-layer drying of fruits and vegetables ranging from 14.42 to $43.26 \mathrm{~kJ} / \mathrm{mol}$; however, few reports obtained $\mathrm{E}_{\text {a }}$ values varying from 78.93 to $130.61 \mathrm{~kJ} / \mathrm{mol}$. The results clearly showed that MP required more energy for removing moisture than AP. It showed that the drying material's composition, type, and characteristics would directly affect the activation energy values.

\section{Changes of polyphenol content, antioxidant activity and color in RW drying of AP and MP}

Figure 3 shows the percentage retention of TPC and antioxidant activity in dried $\mathrm{AP}$ and $\mathrm{MP}$ at different RW drying conditions. For AP, the retention of TPC decreased when the drying temperature was increased from 80 to $85^{\circ} \mathrm{C}$ $(p<0.05)$ but the TPC tended to reach highest retention at the drying temperature of $90^{\circ} \mathrm{C}(85.4 \%)$. For MP, when drying temperature varied from 80 to $95^{\circ} \mathrm{C}$, the TPC retention increased gradually to get highest values at $90^{\circ} \mathrm{C}(85.6 \%)$ $(p<0.05)$ and then insignificantly dropped at $95^{\circ} \mathrm{C}(p \geq 0.05)$. The changes of antioxidant activity were similar to the trend of TPC retention (Figure 3 ).

Figure 3 also indicated that, generally, the loss of TPC and antioxidant activity occurred in the drying process. During drying, the degradation of TPC was mainly due to the action of enzymes, such as polyphenol oxidases (PPOs) and peroxidase (POD) [McSweeney \& Seetharaman, 2015]. The activities of PPOs and POD were previously reported in avocado and mango [Korbel et al., 2013]. The PPOs in avocado pulp were more heat-resistant than those in other fruits and vegetables [Zhou et al., 2016]. However, under heat inactivation at $84^{\circ} \mathrm{C}$ for $15 \mathrm{~min}$, only around $0.2 \%$ of the relative activity of PPOs was maintained in avocado flesh [Gómez-López, 2002]. Vanini et al. [2010] found that fruit maturation, as well as changes in temperature and time, can reduce POD activity. For mango fruit, PPO and POD were most active at temperatures of $50-60^{\circ} \mathrm{C}$ [Korbel et al., 2013] and could be inactivated at high temperatures of $70-90^{\circ} \mathrm{C}$ [Queiroz et al., 2008]. Thus, the PPO and POD could have a significant impact on the degradation of phenolics in avocado and mango. In this study, the results indicated that high temperature $\left(90-95^{\circ} \mathrm{C}\right)$ 

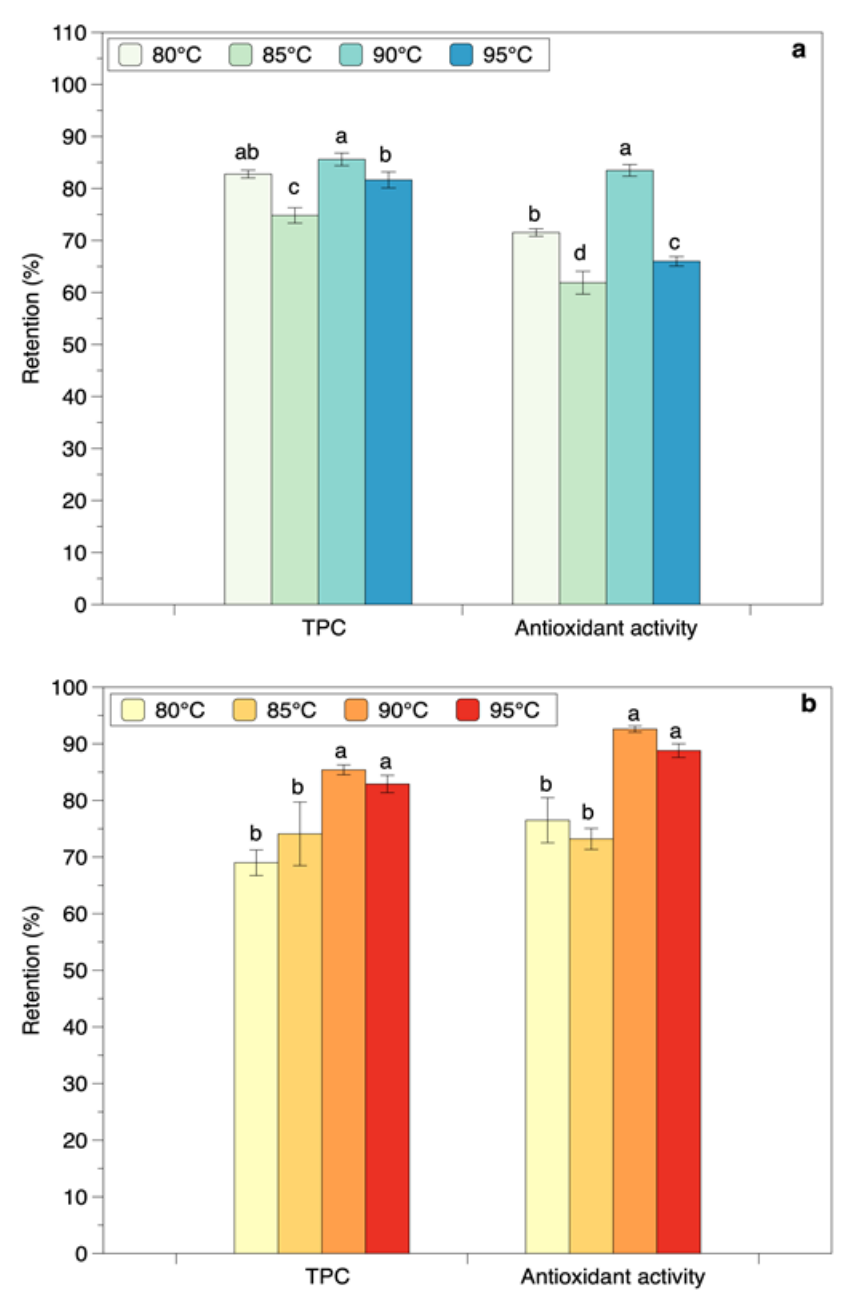

FIGURE 3. The total phenolic content (TPC) and antioxidant activity of powders of avocado pulp (a) and mango pulp (b) obtained by refractance window drying at different temperatures. The same letters above bars within a group indicated that the values are not significantly different $(p \geq 0.05)$.

represented the good control of enzyme activity leading to the highest retention of TPC. Besides, drying at lower temperatures $\left(80-85^{\circ} \mathrm{C}\right)$ consumed more time to complete operation, which could increase the levels of phenolic degradation. In the drying process, the change of moisture content also contributed to the enzyme activity because of the positive correlation between moisture content and water activity [Chen, 2019]. Therefore, in the initial drying process, the high amount of water could accelerate enzymatic reactions, thereby enhacing degradation of phenolics. The higher temperature resulted in higher rate of reactions, causing more loss at drying temperature of $95^{\circ} \mathrm{C}$ than $90^{\circ} \mathrm{C}$. As a consequence, the drying of $\mathrm{AP}$ and MP by the RW technique at $90^{\circ} \mathrm{C}$ allowed retaining the highest TPC.

Phenolics and phytopigments, such as carotenoids, could act as antioxidants [Huyut et al., 2017; Lanfer-Marquez et al., 2005] based on their structure ideal for acting as free radical scavengers, reducing agents or inhibitors of the formation of free radicals under the catalysis of transition metals. As expected, in this study, the correlations between the antioxidant activity and TPC were very strong, with correlation coefficients of 0.825 and 0.881 for avocado and mango powders,
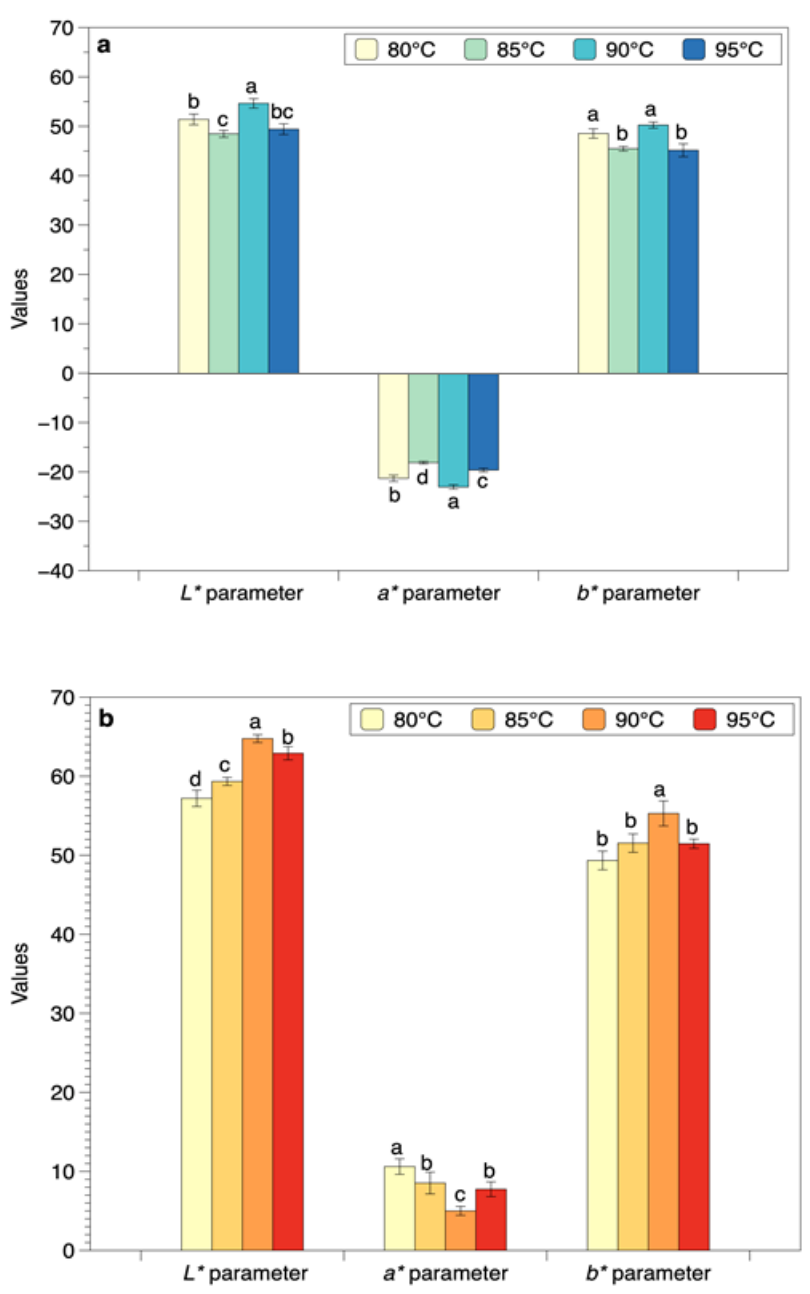

FIGURE 4. The color parameters of powders avocado pulp (a) and mango pulp (b) obtained by refractance window drying at different temperatures. The same letters above bars within a group indicated that the values are not significantly different $(p \geq 0.05)$.

respectively, obtained by RW drying at different temperatures (Table 4 and Table 5). The correlation between TPC and antioxidant activity measured as $\mathrm{DPPH}^{*}$ scavenging activity was also found for dried Thai red curry powder [Inchuen et al., 2010] and dried fruits, such as apples, mulberries, apricots, and black mulberries [Bushra Sultana, 2012]. It was noted that beyond TPC, other antioxidants found in avocado and mango also contributed to the antioxidant activity, such as vitamins, natural pigments, etc. [Lye et al., 2020; Schieber et al., 2000]. However, the high correlation coefficients between TPC and antioxidant activity (more than 0.8 ) indicated that the phenolics played an important role in the total antioxidant activity.

Figure 4 shows values of the color parameters $L^{*}, a^{*}$ and $b^{*}$ of AP and MP dried using RW at different temperatures. Compared to pulp before drying, the $L^{*}$ and $b^{*}$ values of the color of the powders were lower and $a^{*}$ values was higher. It is implied that, in this study, the color of the dried samples became darker (decrease in $L^{*}$ value), less green (increase in $a^{*}$ value), and more yellow (increase of $b^{*}$ value). Besides, the color parameters ( $L^{*}$ and $a^{*}$ ) had strong correlations with TPC (Table 4 and Table 5). 
TABLE 4. Coefficients of Pearson correlation between total phenolic content (TPC), antioxidant activity, and color parameters $\left(L^{*}, a^{*}\right.$, and $\left.b^{*}\right)$ of avocado powders obtained by refractance window drying at different temperatures.

\begin{tabular}{|c|c|c|c|c|}
\hline & $\mathrm{TPC}$ & $\begin{array}{c}\text { Antioxidant } \\
\text { activity }\end{array}$ & $L^{*}$ & $a^{*}$ \\
\hline $\begin{array}{l}\text { Antioxidant } \\
\text { activity }\end{array}$ & $\begin{array}{c}\mathbf{0 . 8 2 5} \\
(0.001)\end{array}$ & 1 & & \\
\hline$L^{*}$ & $\begin{array}{c}\mathbf{0 . 8 1 5} \\
(0.001)\end{array}$ & $\begin{array}{c}\mathbf{0 . 9 2 6} \\
(0.000)\end{array}$ & 1 & \\
\hline$a^{*}$ & $\begin{array}{l}\mathbf{- 0 . 8 9 3} \\
(0.000)\end{array}$ & $\begin{array}{l}\mathbf{- 0 . 9 5 7} \\
(0.000)\end{array}$ & $\begin{array}{l}\mathbf{- 0 . 8 8 9} \\
(0.000)\end{array}$ & 1 \\
\hline$b^{*}$ & $\begin{array}{c}\mathbf{0 . 7 6 0} \\
(0.004)\end{array}$ & $\begin{array}{c}\mathbf{0 . 8 7 9} \\
(0.000)\end{array}$ & $\begin{array}{c}\mathbf{0 . 9 3 7} \\
(0.000)\end{array}$ & $\begin{array}{l}\mathbf{- 0 . 8 6 7} \\
(0.000)\end{array}$ \\
\hline
\end{tabular}

The $p$ values are shown in parentheses. Correlations are considered statistically significant at $p<0.05$ (in bold).

During thermal processing, the discoloration of the product happened, related to pigment destruction and oxidation, enzymatic and non-enzymatic browning, and phenolic polymerization [Bahloul et al., 2009]. For the green-pigmented foods, such as avocado, the less green color was mainly due to the biotransformation of chlorophylls to pheophytins by replacing magnesium ion with hydrogen ions in the center of the porphyrin ring [Rudra et al., 2008]. For foods with the high sugar content, like mango, the browning phenomena were associated with Maillard reaction and caramelization [Potter \& Hotchkiss, 1995]. For fruits containing phenolics, it was reported that the browning phenomena were linked to the enzymatic breakdown of these compounds, producing brown pigments [Dorantes-Alvarez et al., 1998; Hershkovitz et al., 2005]. That explained why the correlation was very strong between TPC and color parameters ( $L^{*}$ value and $a^{*}$ value)

\section{CONCLUSIONS}

This study aimed to determine the RW drying behavior of AP and MP. It was found that the drying process mainly occurred in the falling-rate period. Among the investigated mathematical models, the Weibull model showed the best-predicted power of moisture ratio change during RW drying of AP and MP. The effective diffusivity and activation energy for moisture removal in RW drying of AP and MP were in previously reported ranges of thin-layer drying of food. The RW drying had significant effects on the quality of dried avocado and mango and drying at $90^{\circ} \mathrm{C}$ could retain the highest quality of dried products. It was observed that the RW drying had a high potential in the production of fruit powder from avocado and mango due to the ability to retain more than $80 \%$ of TPC and antioxidant activity. This study found that TPC could be used as a useful criterion for evaluating drying process in terms of dried product quality because TPC was strongly correlated with the antioxidant activity and color parameters.

\section{ACKNOWLEDGEMENTS}

The authors would like to thank Nguyen Tat Thanh University, Ho Chi Minh Univeristy of Technology (HCMUT),
TABLE 5. Coefficients of Pearson correlation between total phenolic content (TPC), antioxidant activity, and color parameters $\left(L^{*}, a^{*}\right.$, and $\left.b^{*}\right)$ of mango powders obtained by refractance window drying at different temperatures.

\begin{tabular}{|c|c|c|c|c|}
\hline & TPC & $\begin{array}{c}\text { Antioxidant } \\
\text { activity }\end{array}$ & $L^{*}$ & $a^{*}$ \\
\hline $\begin{array}{l}\text { Antioxidant } \\
\text { activity }\end{array}$ & $\begin{array}{c}\mathbf{0 . 8 8 1} \\
(0.000)\end{array}$ & 1 & & \\
\hline$L^{*}$ & $\begin{array}{c}\mathbf{0 . 9 0 5} \\
(0.000)\end{array}$ & $\begin{array}{c}\mathbf{0 . 8 8 8} \\
(0.000)\end{array}$ & 1 & \\
\hline$a^{*}$ & $\begin{array}{l}\mathbf{- 0 . 7 4 8} \\
(0.005)\end{array}$ & $\begin{array}{l}\mathbf{- 0 . 6 7 2} \\
(0.017)\end{array}$ & $\begin{array}{l}\mathbf{- 0 . 8 8 3} \\
(0.000)\end{array}$ & 1 \\
\hline$b^{*}$ & $\begin{array}{c}0.514 \\
(0.087)\end{array}$ & $\begin{array}{c}0.529 \\
(0.077)\end{array}$ & $\begin{array}{c}\mathbf{0 . 7 0 5} \\
(0.010)\end{array}$ & $\begin{array}{l}\mathbf{- 0 . 8 0 5} \\
(0.002)\end{array}$ \\
\hline
\end{tabular}

The $p$ values are shown in parentheses. Correlations are considered statistically significant at $p<0.05$ (in bold).

VNU-HCM, The Youth Development Science and Technology Center - Ho Chi Minh Communist Youth Union and Department of Science and Technology of Ho Chi Minh City for permission and for providing facilities, DAKADO Group and Ms. Dao Hai Nguyen for supplying avocado and mango fruits during the research period.

\section{RESEARCH FUNDING}

This research is funded by Nguyen Tat Thanh University, Ho Chi Minh city, Vietnam under grant 2021.01.023.

\section{CONFLICT OF INTERESTS}

The authors declare no conflict of interest.

\section{ORCID IDs}

Quoc-Duy Nguyen https://orcid.org/0000-0001-9097-4471 Thi-Van-Linh Nguyen https://orcid.org/0000-0003-1471-6352

\section{REFERENCES}

1. Abbasi, A.M., Guo, X., Fu, X., Zhou, L., Chen, Y., Zhu, Y., Yan, H., Liu, R.H. (2015). Comparative assessment of phenolic content and in vitro antioxidant capacity in the pulp and peel of mango cultivars. International Journal of Molecular Sciences, 16(6), 13507-13527.

https://doi.org/10.3390/ijms160613507

2. Abonyi, B., Feng, H., Tang, J., Edwards, C., Chew, B., Mattinson, D., Fellman, J. (2002). Quality retention in strawberry and carrot purees dried with Refractance WindowTM system. Journal of Food Science, 67(3), 1051-1056.

https://doi.org/10.1111/j.1365-2621.2002.tb09452.x

3. Abul-Fadl, M., Ghanem, T. (2011). Effect of refractance-window (RW) drying method on quality criteria of produced tomato powder as compared to the convection drying method. World Applied Sciences Journal, 15(7), 953-965.

4. Bahloul, N., Boudhrioua, N., Kouhila, M., Kechaou, N. (2009). Effect of convective solar drying on colour, total phenols and radical scavenging activity of olive leaves (Olea europaea L.). International Journal of Food Science \& Technology, 44(12), 2561-2567. https://doi.org/10.1111/j.1365-2621.2009.02084.x 
5. Berk, Z. (2018). Dehydration. Chapter 22, In Z. Berk (Ed.), Food Process Engineering and Technology ( ${ }^{\text {rd }}$ Edition). Academic Press, pp. 513-566.

https://doi.org/10.1016/B978-0-12-812018-7.00022-1

6. Bloor, S.J. (2001). Overview of methods for analysis and identification of flavonoids. Methods in Enzymology, 335, 3-14.

https://doi.org/10.1016/S0076-6879(01)35227-8

7. Brand-Williams, W., Cuvelier, M.-E., Berset, C. (1995). Use of a free radical method to evaluate antioxidant activity. $L W T-$ Food Science and Technology, 28(1), 25-30.

https://doi.org/10.1016/S0023-6438(95)80008-5

8. Bushra Sultana (2012). Effect of drying techniques on the total phenolic contents and antioxidant activity of selected fruits. Journal of Medicinal Plants Research, 6(1), 161-167.

https://doi.org/10.5897/JMPR11.916

9. Cano-Chauca, M., Stringheta, P., Ramos, A., Cal-Vidal, J. (2005). Effect of the carriers on the microstructure of mango powder obtained by spray drying and its functional characterization. Innovative Food Science \& Emerging Technologies, 6(4), 420-428.

https://doi.org/10.1016/j.ifset.2005.05.003

10. Caparino, O.A., Nindo, C., Tang, J., Sablani, S., Chew, B., Mathison, B., Fellman, J., Powers, J. (2017). Physical and chemical stability of Refractance Window ${ }^{\circledR}$-dried mango (Philippine 'Carabao' var.) powder during storage. Drying Technology, 35(1), $25-37$.

https://doi.org/10.1080/07373937.2016.1157601

11. Caparino, O., Tang, J., Nindo, C., Sablani, S., Powers, J., Fellman, J. (2012). Effect of drying methods on the physical properties and microstructures of mango (Philippine 'Carabao' var.) powder. Journal of Food Engineering, 111 (1), 135-148.

https://doi.org/10.1016/j.jfoodeng.2012.01.010

12. Castañeda-Saucedo, M.C., Valdés-Miramontes, E.H., Tapia-Campos, E., Delgado-Alvarado, A., Bernardino-García, A.C., Rodríguez-Ramírez, M.R., del Pilar Ramirez-Anaya, J. (2014). Effect of freeze-drying and production process on the chemical composition and fatty acids profile of avocado pulp. Revista Chilena de Nutrición, 41(4), 404-411.

https://doi.org/10.4067/S0717-75182014000400009

13. Ceylan, İ., Aktaş, M., Doğan, H. (2007). Mathematical modeling of drying characteristics of tropical fruits. Applied Thermal Engineering, 27(11-12), 1931-1936.

https://doi.org/10.1016/j.applthermaleng.2006.12.020

14. Chaux-Gutiérrez, A.M., Santos, A.B., Granda-Restrepo, D.M., Mauro, M.A. (2017). Foam mat drying of mango: Effect of processing parameters on the drying kinetic and product quality. Drying Technology, 35(5), 631-641.

https://doi.org/10.1080/07373937.2016.1201486

15. Chen, C. (2019). Relationship between water activity and moisture content in floral honey. Foods, 8(1), art. no. 30.

https://doi.org/10.3390/foods8010030

16. Comerford, K.B., Ayoob, K.T., Murray, R.D., Atkinson, S.A. (2016). The role of avocados in complementary and transitional feeding. Nutrients, 8(5), art. no. 316. https://doi.org/10.3390/nu8050316

17. Corzo, O., Bracho, N., Alvarez, C. (2008). Water effective diffusion coefficient of mango slices at different maturity stages during air drying. Journal of Food Engineering, 87(4), 479-484.

https://doi.org/10.1016/j.jfoodeng.2007.12.025
18. Corzo, O., Bracho, N., Alvarez, C. (2010). Weibull model for thin-layer drying of mango slices at different maturity stages. Journal of Food Processing and Preservation, 34(6), 993-1008. https://doi.org/10.1111/j.1745-4549.2009.00433.x

19. Crank, J. (1975). The Mathematics of Diffusion. Oxford University Press.

20. da Cunha, R.L., de la Cruz, A.G., Menegalli, F.C. (2006). Effects of operating conditions on the quality of mango pulp dried in a spout fluidized bed. Drying Technology, 24(4), 423-432. https://doi.org/10.1080/07373930600611869

21. Da Silva, C., Da Silva, C. (2018). Recovery of avocado paste from avocado oil milling process or guacamole processing. U.S. Patent, No. 9,894,908.

22. Degenhardt, A.G., Hofmann, T. (2010). Bitter-tasting and kokumi-enhancing molecules in thermally processed avocado (Persea americana Mill.). Journal of Agricultural and Food Chemistry, 58(24), 12906-12915.

https://doi.org/10.1021/jf103848p

23. Dorantes-Alvarez, L., Parada-Dorantes, L., Ortiz-Moreno, A., Santiago-Pineda, T., Chiralt-Boix, A., Barbosa-Cánovas, G. (1998). Effect of anti-browning compounds on the quality of minimally processed avocados/Efecto de inhibidores del pardeamiento en la calidad de aguacates mínimamente procesados. Food Science and Technology International, 4(2), 107-113. https://doi.org/10.1177/108201329800400205

24. Doymaz, İ. (2012). Evaluation of some thin-layer drying models of persimmon slices (Diospyros kaki L.). Energy Conversion and Management, 56, 199-205.

https://doi.org/10.1016/j.enconman.2011.11.027

25. Fitzpatrick, J.J., Ahrné, L. (2005). Food powder handling and processing: Industry problems, knowledge barriers and research opportunities. Chemical Engineering and Processing: Process Intensification, 44(2), 209-214.

https://doi.org/10.1016/j.cep.2004.03.014

26. Germer, S.P.M., Tonin, I.P., de Aguirre, J.M., Alvim, I.D., Ferrari, C.C. (2018). Influence of process variables on the drum drying of mango pulp. Drying Technology, 36(12), 1488-1500. https://doi.org/10.1080/07373937.2017.1410707

27. Gómez-López, V.M. (2002). Some biochemical properties of polyphenol oxidase from two varieties of avocado. Food Chemistry, 77(2), 163-169.

https://doi.org/10.1016/S0308-8146(01)00331-4

28. Gómez-Pérez, L.S., Navarrete, C., Moraga, N., Rodríguez, A., Vega-Gálvez, A. (2020). Evaluation of different hydrocolloids and drying temperatures in the drying kinetics, modeling, color, and texture profile of murta (Ugni molinae Turcz) berry leather. Journal of Food Process Engineering, 43(2), art. no. e13316. https://doi.org/10.1111/jppe.13316

29. Gulati, T., Datta, A.K. (2015). Mechanistic understanding of case-hardening and texture development during drying of food materials. Journal of Food Engineering, 166, 119-138. https://doi.org/10.1016/j.jfoodeng.2015.05.031

30. Haytowitz, D.B., Wu, X., Bhagwat, S. (2018). USDA Database for the Flavonoid Content of Selected Foods, Release 3.3. US Department of Agriculture, Agricultural Research Service, Nutrient Data Laboratory.

31. Hershkovitz, V., Saguy, S.I., Pesis, E. (2005). Postharvest application of 1-MCP to improve the quality of various avocado cultivars. Postharvest Biology and Technology, 37(3), 252-264.

https://doi.org/10.1016/j. postharvbio.2005.05.003 
32. Huyut, Z., Beydemir, Ş., Gülçin, İ. (2017). Antioxidant and antiradical properties of selected flavonoids and phenolic compounds. Biochemistry Research International, 2017, art. no. 7616791. https://doi.org/10.1155/2017/7616791

33. Inchuen, S., Narkrugsa, W., Pornchaloempong, P. (2010). Effect of drying methods on chemical composition, color and antioxidant properties of thai red curry powder. Kasetsart Journal - Natural Science, 44, 142-151.

34. ISO 14502-1:2005 (2005). International Organization for Standardization. Determination of substances characteristic of green and black tea - Part 1: Content of total polyphenols in tea-colorimetric method using Folin-Ciocalteu reagent, p. 10.

35. Jaya, S., Das, H. (2003). A vacuum drying model for mango pulp. Drying Technology, 21 (7), 1215-1234. https://doi.org/10.1081/DRT-120023177

36. Jaya, S., Das, H., Mani, S. (2006). Optimization of maltodextrin and tricalcium phosphate for producing vacuum dried mango powder. International Journal of Food Properties, 9(1), 13-24. https://doi.org/10.1080/10942910500217666

37. Ju, H.Y., Zhao, S.H., Mujumdar, A., Fang, X.M., Gao, Z.J., Zheng, Z.A., Xiao, H.W. (2018). Energy efficient improvements in hot air drying by controlling relative humidity based on Weibull and Bi-Di models. Food and Bioproducts Processing, 111, 20-29. https://doi.org/10.1016/j.fbp.2018.06.002

38. Kassim, A., Workneh, T., Bezuidenhout, C. (2013). A review on postharvest handling of avocado fruit. African Journal of Agricultural Research, 8(21), 2385-2402.

39. Korbel, E., Servent, A., Billaud, C., Brat, P. (2013). Heat inactivation of polyphenol oxidase and peroxidase as a function of water activity: A case study of mango drying. Drying Technology, 31 (13-14), 1675-1680. https://doi.org/10.1080/07373937.2013.808659

40. Lanfer-Marquez, U.M., Barros, R.M., Sinnecker, P. (2005). Antioxidant activity of chlorophylls and their derivatives. Food Research International, 38(8-9), 885-891. https://doi.org/10.1016/j.foodres.2005.02.012

41. Lye, H.S., Ong, M.K., Teh, L.K., Chang, C.C., Wei, L.K. (2020). Avocado. Chapter 4, In C.M. Galanakis (Ed.), Valorization of Fruit Processing By-Products. Academic Press, pp. 67-93. https://doi.org/10.1016/B978-0-12-817106-6.00004-6

42. Madamba, P.S., Driscoll, R.H., Buckle, K.A. (1996). The thin-layer drying characteristics of garlic slices. Journal of Food Engineering, 29(1), 75-97. https://doi.org/10.1016/0260-8774(95)00062-3

43. Marquardt, D.W. (1963). An algorithm for least-squares estimation of nonlinear parameters. Journal of the Society for Industrial and Applied Mathematics, 11 (2), 431-441. https://doi.org/10.1137/0111030

44. McSweeney, M., Seetharaman, K. (2015). State of polyphenols in the drying process of fruits and vegetables. Critical Reviews in Food Science and Nutrition, 55(5), 660-669. https://doi.org/10.1080/10408398.2012.670673

45. Nguyen, T.V., Nguyen, M.D., Nguyen, D.C., Bach, L.G., Lam, T.D. (2019). Model for thin layer drying of lemongrass (Cymbopogon citratus) by hot air. Processes, 7(1), art. no. 21. https://doi.org/10.3390/pr7010021

46. Nindo, C.I., Tang, J. (2007). Refractance window dehydration technology: A novel contact drying method. Drying Technology, 25(1), 37-48.

https://doi.org/10.1080/07373930601152673
47. Occena-Po, L.G. (2006). Banana, mango, and passion fruit. Chapter 33, In Y.H. Hui (Ed.), Handbook of Fruits and Fruit Processing. Wiley Online Library, p. 635. https://doi.org/10.1002/9780470277737.ch33

48. Ochoa-Martínez, C., Quintero, P., Ayala, A., Ortiz, M. (2012). Drying characteristics of mango slices using the Refractance Window ${ }^{\mathrm{TM}}$ technique. Journal of Food Engineering, 109(1), 69-75. https://doi.org/10.1016/j.jfoodeng.2011.09.032

49. Onwude, D.I., Hashim, N., Janius, R.B., Nawi, N.M., Abdan, K. (2016). Modeling the thin-layer drying of fruits and vegetables: A review. Comprehensive Reviews in Food Science and Food Safety, 15(3), 599-618.

https://doi.org/10.1111/1541-4337.12196

50. Pala, M., Mahmutoğlu, T., Saygi, B. (1996). Effects of pretreatments on the quality of open-air and solar dried apricots. Food/ Nahrung, 40(3), 137-141.

https://doi.org/10.1002/food.19960400308

51. Parisotto, E.I.B., Teleken, J.T., Laurindo, J.B., Carciofi, B.A.M. (2020). Mathematical modeling and experimental assessment of the cast-tape drying. Drying Technology, 38(8), 1024-1035. https://doi.org/10.1080/07373937.2019.1610768

52. Potter, N.N., Hotchkiss, J.H. (1995). Food Science. 5 Edition. Springer Science+ Business Media, LLC New York. https://doi.org/10.1007/978-1-4615-4985-7

53. Pu, Y.Y., Sun, D.W. (2017). Combined hot-air and microwavevacuum drying for improving drying uniformity of mango slices based on hyperspectral imaging visualisation of moisture content distribution. Biosystems Engineering, 156, 108-119.

https://doi.org/10.1016/j.biosystemseng.2017.01.006

54. Queiroz, C., Mendes Lopes, M.L., Fialho, E., Valente-Mesquita, V.L. (2008). Polyphenol oxidase: Characteristics and mechanisms of browning control. Food Reviews International, 24(4), 361-375.

https://doi.org/10.1080/87559120802089332

55. Rafidah, H., Ando, Y., Amin, I., Shirai, Y., Mohd Ali, H. (2014). Enhanced polyphenol content and antioxidant capacity in the edible portion of avocado dried with superheated-steam. International Journal of Advanced Research, 8, 241-248.

56. Raghavi, L., Moses, J., Anandharamakrishnan, C. (2018). Refractance window drying of foods: A review. Journal of Food Engineering, 222, 267-275.

https://doi.org/10.1016/j.jfoodeng.2017.11.032

57. Rajoriya, D., Bhavya, M.L., Hebbar, H.U. (2021). Impact of process parameters on drying behaviour, mass transfer and quality profile of refractance window dried banana puree. $L W T$ - Food Science and Technology, 145, art. no. 111330.

https://doi.org/10.1016/j.Iwt.2021.111330

58. Rajoriya, D., Shewale, S.R., Hebbar, H.U. (2019). Refractance window drying of apple slices: Mass transfer phenomena and quality parameters. Food and Bioprocess Technology, 12(10), 1646-1658. https://doi.org/10.1007/s11947-019-02334-7

59. Ramaswamy, H.S., Marcotte, M. (2005). Food processing: Principles and applications. CRC Press, Boca Raton. https://doi.org/10.1201/9780203485248

60. Rudra, S.G., Singh, H., Basu, S., Shivhare, U.S. (2008). Enthalpy entropy compensation during thermal degradation of chlorophyll in mint and coriander puree. Journal of Food Engineering, 86(3), 379-387.

https://doi.org/10.1016/j.jfoodeng.2007.10.020 
61. Schieber, A., Ullrich, W., Carle, R. (2000). Characterization of polyphenols in mango puree concentrate by HPLC with diode array and mass spectrometric detection. Innovative Food Science \& Emerging Technologies, 1(2), 161-166.

https://doi.org/10.1016/S1466-8564(00)00015-1

62. Shariful, H., Parveen, B., Maksuda, K., Islam, S.N. (2015). Total carotenoid content in some mango (Mangifera indica) varieties of Bangladesh. International Journal of Pharmaceutical Sciences and Research, 6(11), 4875-4878.

63. Souza, D.S., Marques, L.G., Gomes, E., Narain, N. (2015). Lyophilization of avocado (Persea americana Mill.): Effect of freezing and lyophilization pressure on antioxidant activity, texture, and browning of pulp. Drying Technology, 33(2), 194-204.

https://doi.org/10.1080/07373937.2014.943766

64. Temu, A.T. (2013). Effect of temperature and slice size on avocado pulp drying rate and oil yield. Tanzania Journal of Engineering and Technology, 34(2), 116-124.

https://doi.org/10.52339/tjet.v34i2.464

65. Tzempelikos, D.A., Vouros, A.P., Bardakas, A.V., Filios, A.E., Margaris, D.P. (2015). Experimental study on convective drying of quince slices and evaluation of thin-layer drying models. Engineering in Agriculture, Environment and Food, 8(3), 169-177. https://doi.org/10.1016/j.eaef.2014.12.002

66. Uribe, E., Vega-Gálvez, A., Di Scala, K., Oyanadel, R., Saavedra Torrico, J., Miranda, M. (2011). characteristics of convective drying of pepino fruit (Solanum muricatum Ait.): application of Weibull distribution. Food and Bioprocess Technology, 4(8), 1349-1356. https://doi.org/10.1007/s11947-009-0230-y

67. Vanini, L.S., Kwiatkowski, A., Clemente, E. (2010). Polyphenoloxidase and peroxidase in avocado pulp (Persea americana Mill.). Food Science and Technology, 30, 525-531.

https://doi.org/10.1590/S0101-20612010000200036
68. Vega-Mercado, H., Góngora-Nieto, M.M., Barbosa-Cánovas, G.V. (2001). Advances in dehydration of foods. Journal of Food Engineering, 49(4), 271-289. https://doi.org/10.1016/S0260-8774(00)00224-7

69. Wang, W., Bostic, T.R., Gu, L. (2010). Antioxidant capacities, procyanidins and pigments in avocados of different strains and cultivars. Food Chemistry, 122(4), 1193-1198.

https://doi.org/10.1016/j.foodchem.2010.03.114

70. Wang, Y., Lu, Z., Lv, F., Bie, X. (2009). Study on microencapsulation of curcumin pigments by spray drying. European Food Research and Technology, 229(3), 391-396. https://doi.org/10.1007/s00217-009-1064-6

71. Yao, L., Fan, L., Duan, Z. (2020). Effect of different pretreatments followed by hot-air and far-infrared drying on the bioactive compounds, physicochemical property and microstructure of mango slices. Food Chemistry, 305, art. no. 125477.

https://doi.org/10.1016/j.foodchem.2019.125477

72. Zhou, L., Tey, C.Y., Bingol, G., Bi, J. (2016). Effect of microwave treatment on enzyme inactivation and quality change of defatted avocado puree during storage. Innovative Food Science \& Emerging Technologies, 37, 61-67.

https://doi.org/10.1016/j.ifset.2016.08.002

73. Zotarelli, M.F., Carciofi, B.A.M., Laurindo, J.B. (2015). Effect of process variables on the drying rate of mango pulp by Refractance Window. Food Research International, 69, 410-417. https://doi.org/10.1016/j.foodres.2015.01.013

74. Zotarelli, M.F., da Silva, V.M., Durigon, A., Hubinger, M.D., Laurindo, J.B. (2017). Production of mango powder by spray drying and cast-tape drying. Powder Technology, 305, 447-454. https://doi.org/10.1016/j. powtec.2016.10.027 